\title{
Microsatellite Instability and Survival in Stage II Colorectal Cancer: A Systematic Review and Meta-analysis
}

\author{
FAUSTO PETRELLI $^{1}$, MICHELE GHIDINI ${ }^{2}$, MARY CABIDDU ${ }^{1}$, EZIO PEZZICA ${ }^{3}$, \\ DANIELA CORTI ${ }^{3}$, LUCA TURATI $^{4}$, ANTONIO COSTANZO ${ }^{4}$, ANTONIO VARRICCHIO ${ }^{4}$, \\ ANTONIO GHIDINI ${ }^{5}$, SANDRO BARNI ${ }^{1}$ and GIANLUCA TOMASELLO ${ }^{6}$ \\ ${ }^{1}$ Oncology Unit, ASST Bergamo Ovest, Treviglio, Italy; \\ ${ }^{2}$ Medical Oncology Unit, Fondazione IRCCS Ca' Granda Ospedale Maggiore Policlinico, Milan, Italy; \\ ${ }^{3}$ Pathology Unit, ASST Bergamo Ovest, Treviglio, Italy; \\ ${ }^{4}$ Surgical Oncology Unit, ASST Bergamo Ovest, Treviglio, Italy; \\ ${ }^{5}$ Casa di Cura Igea, Oncology Unit, Milan, Italy; \\ ${ }^{6}$ Oncology Unit, Niguarda Cancer Center, Grande Ospedale Metropolitano Niguarda, Milan, Italy
}

\begin{abstract}
Background/Aim: About 15-20\% of colorectal cancers (CRCs) have deficiency in a mismatch repair (MMR) protein. MMR has a high level of microsatellite instability (MSI-H). We have conducted this review and meta-analysis to determine the prognostic role of MSI-H status in stage II CRC. Materials and Methods: We searched PubMed, EMBASE, The Cochrane Library, Web of Science, and SCOPUS for studies reporting data on overall survival (OS) and disease-free or relapse-free survival (DFS or RFS) for MSI-H compared to microsatellite stable (MSS) CRC. Results: A total of 39 studies were analysed, including 12,110 patients. MSI-H status was associated with a significantly reduced risk of death $(H R=0.64,95 \% C I=0.52-0.8, p<0.01)$ and relapse $(H R=0.59$, $95 \% C I=0.45-0.77, p<0.01)$ in stage II CRC. Conclusion: MSI-H represents an important prognostic determinant in stage II CRC and may be considered when estimating the risk of recurrence in stage II CRC.
\end{abstract}

Stage II colorectal cancer (CRC) is usually associated with a good prognosis; five-year overall survival (OS) rates range from 75 to $87.5 \%$ (1). However, the administration of postoperative

This article is freely accessible online.

Correspondence to: Fausto Petrelli, MD, Oncology Unit, Oncology Department, ASST Bergamo Ovest, Piazzale Ospedale 1, 24047, Treviglio (BG) Italy. Tel: +39 0363424420, Fax: +39 0363424380, e-mail: faupe@libero.it

Key Words: Colorectal cancer, microsatellite instability, metaanalysis, prognosis, stage II, review. 5-fluorouracil (5-FU)-based chemotherapy in this group of patients remains controversial, since it has been shown that survival gain generally does not exceed 5\% (2). Several prognostic factors have been evaluated in order to identify a high-risk stage II CRC subgroup, for which adjuvant chemotherapy would have a better indication. High-risk features include an inadequate sampling of lymph nodes (less than 12), extension of primary tumor (pT4), poor differentiation (grade 3 ), acute onset of the disease with obstruction or perforation, lymph-vascular and perineural invasion, and close, indeterminate or positive resection margins (3).

Recently, microsatellite instability status (MSI) has been identified as a reliable prognostic indicator in stage II CRC, with an additional role in predicting the lack of benefit of 5FU-based adjuvant chemotherapy (4-6). These data have been replicated in the large randomized phase III Quick and Simple and Reliable (QUASAR) trial, where 2,291 patients with stage II CRC were randomized to receive adjuvant chemotherapy with 5-FU and folinic acid or to undergo observation. An analysis performed on these patients found a prognostic role for MMR status, even if it was not shown to be predictive of any benefit from adjuvant chemotherapy (6).

Although a number of molecular markers of outcome in CRC has been proposed (BRAF/KRAS), there has been no clear consensus about their role in early stage CRC. Despite that a series of studies have investigated the relationship between MSI status and survival in CRC patients, they often included mixed populations of early (stage II-III) and advanced CRCs (stages IV).

The aim of our study was to evaluate the prognostic significance of MMR status in stage II CRC by analyzing all the available data coming from prospective and retrospective studies. 


\section{Materials and Methods}

We performed this systematic review and meta-analysis in accordance with the PRISMA guidelines and the Cochrane Handbook for Systematic Reviews of Interventions.

Search strategy. References for this systematic review and metaanalysis were identified through searches of PubMed, the Cochrane Library, SCOPUS, Web of Science, and EMBASE from inception to September 2019. Searches included the terms: (colon OR colorectal) and (cancer OR carcinoma) and (MMR OR MSI OR microsatellite instability OR replication error OR mismatch repair) and (stage 2 OR stage II) and (hazard ratio). Manual selection of relevant studies was also carried out based on the related articles function. The citation lists of all retrieved articles were analyzed to identify other potentially relevant reports.

Inclusion criteria and data extraction. Published studies were eligible if survival was analyzed in CRC cases stratified by MSI status by either genotyping or immunohistochemistry. In fact, MSI status can be assessed using a panel of five microsatellite biomarkers. The instability of two or more of these five microsatellite loci (>30\%) was defined as high-frequency MSI (MSI$\mathrm{H}$ ), whereas instability of one or no marker characterized as lowfrequency MSI (MSI-L) or stable microsatellite status (MSS) (7). An alternative method of MMR status evaluation is the analysis of MMR gene protein products (MLH1, MSH2, MSH6, and PMS2) using immunohistochemical (IHC) staining. Tumors that yielded negative staining results for at least one of the 4 MMR proteins, were classified as dMMR tumors, and all others were classified as pMMR tumors. Assignment of MSI status into corresponding groups (MSI$\mathrm{H}$ or MSI-low or MSS) was performed using data provided in each contributing study. The primary outcome of interest was overall survival (OS), and the secondary endpoint was disease-free survival (DFS). Only studies providing at least one piece of information on survival were included. In cases of overlapping and duplicated data sets, only the most recent data sets were taken into consideration. Only studies published in the English language and in peer-review journals were included. Data from review articles, case reports, abstracts, and letters were not included. Two authors (FP and MC) conducted the search and identification independently, and the selection of an article was reached by consensus with a third author (GT). The following information was extracted from each report by the two authors independently: author/year of publication, country, patient number, type of study, rate of MSI tumors, adjuvant therapy exposure (rate), type of MSI evaluation method, BRAF status, survival data available, and type of analysis.

Statistical analysis. The association of MSI with OS and DFS was derived as a weighted average of study-specific estimates of the hazard ratio (HR), using inverse variance weights. The logHR and the corresponding variance were used as data points for pooling purposes. If data was only presented as survival curves, rates of survival were extracted at specified times to reconstruct the HR estimate and its variance, under the assumption that the rate of patients censored was constant during the study follow-up, according to the method described by Parmar et al. (8). HRs obtained according to multivariate analysis were used when provided. Otherwise, values derived from univariate analysis were considered. Each covariate tested in the multivariate analysis resulted to be significantly associated with the outcome of interest in the univariate analysis. By convention, an observed $\mathrm{HR}$ of $<1$ implied better survival for MSI cancers.

The percentage variability of the pooled HR attributable to heterogeneity among studies was quantified using the $\mathrm{I}^{2}$ statistic and Cochran's Q statistics (9). Summary data from published studies was pooled using fixed-, and when heterogeneity was high $(p<0.05$ or $\mathrm{I}^{2}>50 \%$ ), random-effects models. Evidence of publication bias was examined by constructing funnel plots of HRs (Begg's test). Publication bias was also formally assessed by the Egger method (10). Sensitivity analysis for OS analysis was performed according to the race of participants (Asiatic vs. non-Asiatic), type of MSI evaluation (IHC vs. biomarkers), year of publication (before 2008 vs. 2008-2017), quality (high vs. low quality papers), type of analysis (uni- $v s$. multi-variate analysis), number of patients (above $v s$. below median number), type of study (trial vs. retrospective series), and rate of adjuvant chemotherapy.

We used the Newcastle-Ottawa Scale (NOS) for the risk of bias assessment (11). This scale assesses the likelihood of bias in three domains: 1) selection of the study groups; 2) comparability of groups; and 3) ascertainment of exposure and outcome. Studies with scores $\geq 7$ were considered as having a low risk of bias, scores of 46 as having a moderate risk of bias, and scores $<4$ as having a high risk of bias. We assessed that follow-up was adequate if the median follow-up was more than five years.

Data was entered into the Comprehensive Meta-Analysis software v 3.3.070 (November 20th, 2014) and Review Manager (RevMan) Version 5.3. (Copenhagen: The Nordic Cochrane Centre, The Cochrane Collaboration, 2014).

\section{Results}

A total of 1,304 potentially relevant citations were reviewed (Figure 1). Ultimately, 39 studies (12-51) published from 1999 to 2019, reporting the prognostic value of MSI status in stage II CRC were analyzed, with a median follow up of 68.5 months. The total number of patients included was 12,110 ranging from 31 to 1,436 patients per study (median=213). Median age was 65.5 years. The major characteristics are shown in Table I.

In $n=32$ publications, a retrospective analysis of stage II CRC patients was presented; $n=6$ were retrospective analyses of phase III trials; and $n=1$ was a prospective series. According to race, most patients were of non-Asiatic origin $(n=35)$ and the remaining publications $(n=4)$ included Asian subjects. MSI status was diagnosed in $21 \%$ of CRC cases analyzed in the included studies (range 6-57.5\%). In the $n=2$ studies, it was not reported. The analysis was performed with IHC detection in $\mathrm{n}=15$ studies and with the biomarker method in $n=22$, while in one, both methods were used. In the article by Hansen et al., the method of MSI evaluation was not reported. Delivery of adjuvant chemotherapy was $19.5 \%$ (range $=0-100 \%$ ). In $\mathrm{n}=7$ publications data about adjuvant chemotherapy was unknown.

The quality of paper expressed by the NOS scale ranged from five to nine, with $75 \%$ including studies of high quality (NOS scale scores from seven to nine). 


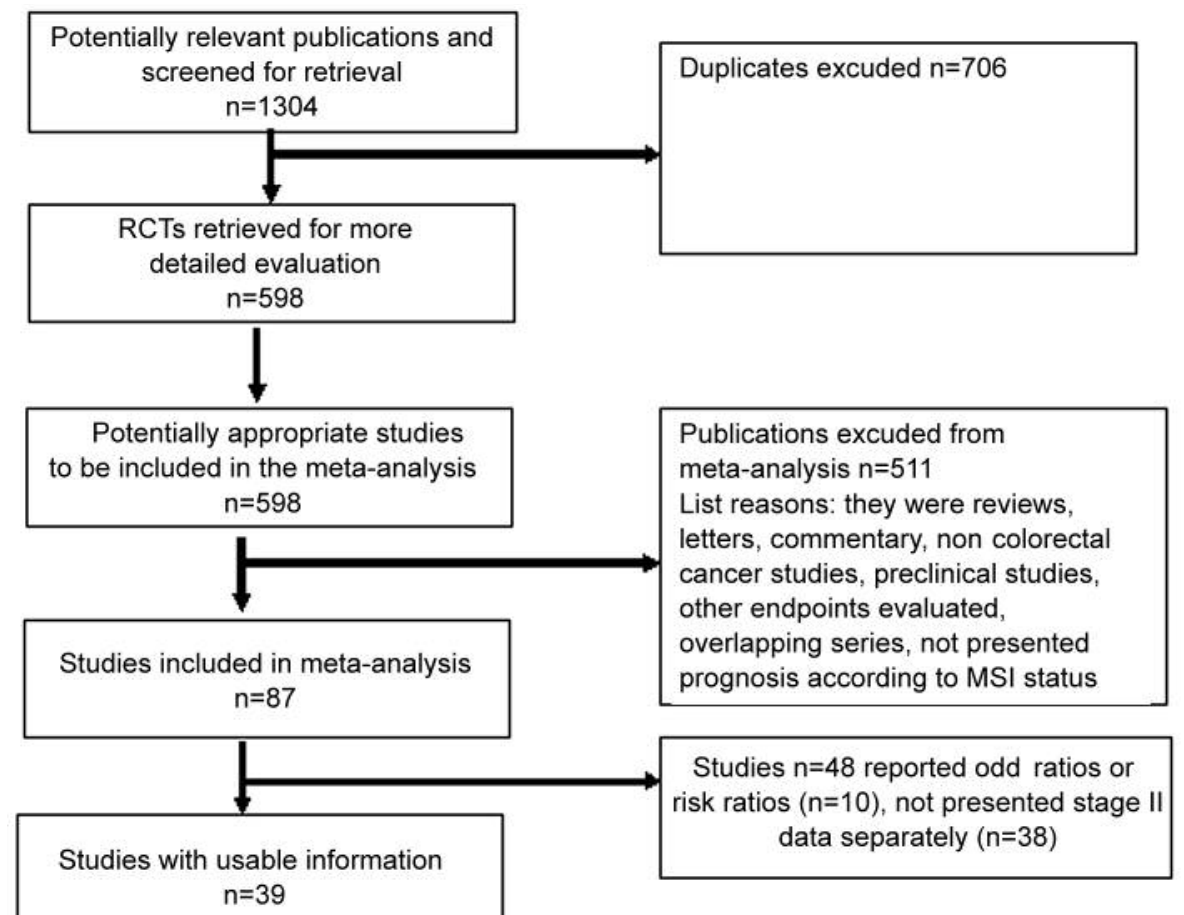

Figure 1. Literature search flow diagram.

Meta-analysis of overall survival. Because the heterogeneity test showed a moderate level of heterogeneity $\left(\mathrm{I}^{2}=58 \%\right.$, $p<0.01$ ) between studies, a random-effects model was used for analysis. A pooled HR of $0.64(95 \% \mathrm{CI}=0.52-0.8, p<0.01)$ from $n=27$ studies showed that patients with MSI CRC were associated with a reduced risk of death (Figure 2). In $n=3$ studies, HRs were calculated from survival curves because they were not provided by the authors. After exclusion of the least (47) and most favorable (38) HRs the final result did not change significantly.

Meta-analysis of disease-free or relapse-free survival. Because the heterogeneity test showed a moderate level of heterogeneity $\left(\mathrm{I}^{2}=57 \%, p<0.01\right)$ between studies, a randomeffects model was used even for this analysis. A pooled HR of $0.59(95 \% \mathrm{CI}=0.45-0.77, p<0.01)$ from $\mathrm{n}=27$ studies showed that patients with MSI CRC were associated with a reduced risk of relapse (Figure 3 ). In $n=8$ publications, other endpoints were used for time-to-event analysis of relapse. Only in $n=1$ study HR was calculated from survival curves because was not provided by authors. After exclusion of the least (35) and most favorable (37) HRs the final result did not change significantly.

Subgroup analysis and meta-regression for overall survival analysis. The subgroup analysis (Table II), performed according to the number of patients (above or below the calculated median number), showed that in the largest studies ( $>213$ subjects) the effect size was inferior compared to the smallest studies $(<190$ subjects): $\mathrm{HR}=0.69(95 \% \mathrm{CI}=0.53-0.88)$ and $0.51(95 \% \mathrm{CI}=0.40-$ 0.66 ) respectively ( $p=0.11$ for subgroups difference). Analysis according to race (Asian vs. non-Asian race of included patients) led to a significant effect on OS for Asian studies but with only $n=3$ studies with this origin ( $p$ for difference $=0.038$ ). According to the type of MSI analysis for biomarkers evaluation, when either a polymerase chain reaction or IHC method were used, the positive association of MSI status with survival was significant, even if a deeper association was found with the former $(\mathrm{HR}=0.51,95 \% \mathrm{CI}=0.4-0.65 ; p<0.001 v s$. $\mathrm{HR}=0.77,95 \% \mathrm{CI}=0.60-0.99 ; p=0.044: p$ for difference=0.006). Since only one publication was of prospective nature in the OS analysis, subgroup analysis according to types of studies was not performed. Meta-regression showed that the effect size did not depend on the rate of adjuvant chemotherapy ( $p=0.14)$.

Under the random effects model, the pooled HR obtained from both multivariate and univariate HRs were not significantly different: $0.67(95 \% \mathrm{CI}=0.55-0.82 ; p<0.001)$ and $\quad 0.57 \quad(95 \% \mathrm{CI}=0.41-0.81, \quad p=0.002 ; \quad p$ for difference $=0.44)$. On the contrary, significance was maintained only in high quality $(\mathrm{HR}=0.61,95 \% \mathrm{CI}=0.48$ $0.74 ; p<0.001)$ but not in low quality studies $(\mathrm{HR}=0.62$, $95 \% \mathrm{CI}=0.34-1.16 ; p$ for difference $=0.96)$. Finally, in more 
Table I. Characteristics of included studies.

\begin{tabular}{|c|c|c|c|c|c|c|}
\hline Author & Year & Type of study & $\mathrm{N}^{\circ}$ of pts & $\begin{array}{l}\text { Median follow up } \\
\text { (months) }\end{array}$ & $\begin{array}{l}\text { Median age } \\
\text { (years) }\end{array}$ & Country \\
\hline Aparicio & 2013 & Retrospective & 91 & 14.8 & NA & France \\
\hline Curran & 1999 & Retrospective & 159 & 94.8 & 69.7 & Ireland \\
\hline De Weger & 2011 & Retrospective (phase III study) & 117 & 180 & NA & The Netherlands \\
\hline Deschoolmeester & 2008 & Retrospective & 130 & NA & 64.5 & Belgium \\
\hline Donada & 2010 & Retrospective & 31 & 91.2 & NA & Italy \\
\hline Gray & 2011 & Retrospective (phase III study) & 1436 & NA & NA & UK \\
\hline Gryfe & 2000 & Retrospective & 173 & 86.4 & 43 & Canada \\
\hline Guidoboni & 2001 & Retrospective & 55 & 74 & NA & Italy \\
\hline Hansen & 2014 & Retrospective & 554 & NA & 74 & Denmark \\
\hline Hveem & 2014 & Retrospective & 278 & 69 & 74 & Norway \\
\hline Kevans & 2011 & Retrospective & 258 & NA & 70.6 & Ireland \\
\hline Kim & 2015 & Retrospective & 860 & 60.3 & 61 & Korea \\
\hline Klingbiel & 2014 & Retrospective (phase III study) & 395 & 69.1 & 57.5 & Europe \\
\hline Kopetz & 2015 & Retrospective & 416 & 81 & 67 & International \\
\hline Krajewska & 2015 & Retrospective & 106 & 66 & 55 & Korea \\
\hline Lanza & 2006 & Retrospective & 393 & 90.5 & 66 & Italy \\
\hline Maak & 2013 & Retrospective & 132 & 101 & 65 & Germany \\
\hline Malesci & 2007 & Retrospective & 246 & 52 & 65 & Italy \\
\hline Marcker Espersen & 2016 & Retrospective & 144 & 92 & 73 & Denmark \\
\hline Nazemalhosseini Mojarad & 2016 & Retrospective & 73 & 60.2 & NA & Iran \\
\hline Niedzwiecki & 2016 & Retrospective (phase III study) & 393 & 97.2 & 64 & USA \\
\hline Nitsche & 2012 & Retrospective & 232 & 97 & 66 & Germany \\
\hline Ozawa & 2014 & Retrospective & 164 & 69 & 68 & Japan \\
\hline Park & 2003 & Retrospective & 142 & 42 & 67.7 & France \\
\hline Roth & 2010 & Retrospective (phase III study) & 409 & 68 & NA & Europe \\
\hline Salazar & 2011 & Retrospective & 114 & 65 & 68.5 & Europe \\
\hline Samowitz & 2001 & Retrospective & 402 & 62 & NA & USA \\
\hline Sargent & 2011 & Retrospective & 241 & 60 & 74 & USA \\
\hline Shin & 2014 & Retrospective & 115 & 38 & 61 & Korea \\
\hline Sinicrope & 2011 & Retrospective (phase III trials) & 778 & 96 & 62 & International \\
\hline Slik & 2017 & Retrospective & 173 & 57 & NA & Finland/Libya \\
\hline Tian & 2012 & Retrospective & 263 & NA & NA & Europe \\
\hline Touchefeu & 2016 & Retrospective & 195 & $>36$ & 73.4 & France \\
\hline Turner & 2015 & Prospective series & 396 & 61.2 & NA & Australia \\
\hline Vogelaar & 2015 & Retrospective & 186 & NA & NA & The Netherlands \\
\hline Wang & 2003 & Retrospective & 154 & 75 & NA & Australia \\
\hline Yang & 2015 & Retrospective & 460 & 41.5 & 64.5 & China \\
\hline Zhang & 2013 & Retrospective & 735 & 66 & NA & China \\
\hline
\end{tabular}

NA: Not available; pts: patients.

recent studies (2008-2017) $\mathrm{HR}$ for OS was 0.65 $(95 \% \mathrm{CI}=0.5-0.85 ; p=0.002)$ and it was 0.54 in older studies (95\% CI $=0.43-0.68 ; p<0.001 ; p$ for difference=0.29).

The funnel plot $(p=0.21$; Figure 4$)$ and Egger test $(p=0.11)$ for OS did not indicate the existence of obvious publication bias. Also, trim and fill analysis did not change the pooled estimates of the meta-analysis $(\mathrm{HR}=0.64$; $95 \% \mathrm{CI}=0.52-0.78)$.

\section{Discussion}

Patients with stage II CRC have a disease-free survival of approximately $80 \%$ with surgery alone, but $20 \%$ recur within five years and those patients potentially require adjuvant treatment after colectomy (51). Common prognostic factors such as pT stage, grade, number of lymph nodes removed, and emergency surgery can discriminate high-risk patients, although the OS benefit with fluoropyrimidine-based chemotherapy in stage II disease is at best $5 \%$. But neither the QUASAR study nor the previous Cochrane metaanalyses were able to confirm a survival benefit in stage II disease $(2,51)$. Conversely the prognostic role of MSI status split by stage has not systematically evaluated in previous meta-analysis, in particular for stage II CRC. Within this scenario, we aimed to discover and validate potential prognostic factors able to discriminate patients, with 


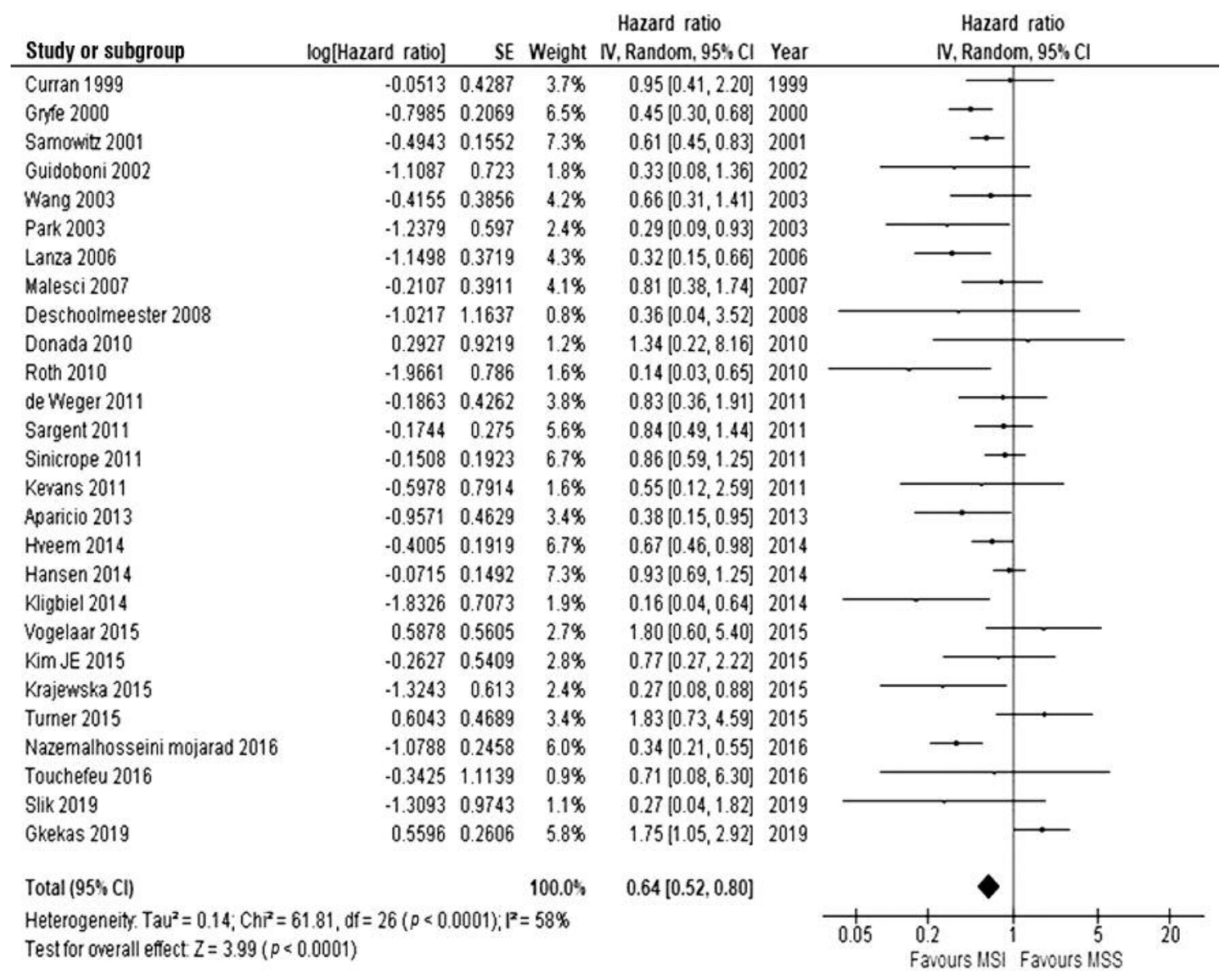

Figure 2. Meta-analysis of overall survival for MSI vs. MSS colorectal cancer.

significant risk of recurrence, who may need postoperative therapy after resection.

Previous systematic review and meta-analysis that have evaluated MSI status and survival did not split and analyze stage II CRC separately from more advanced disease stages. In our meta-analysis, including more than 11,000 patients and 38 studies, we can confirm that MSI status, evaluated by molecular or IHC testing, is a significant and favorable prognostic factor for both survival and relapse in stage II CRC. Compared to MSS CRCs, patients with MSI have a $40 \%$ reduced risk of death and recurrence and the benefit in OS is independent of other prognostic factors according to multivariate analysis and the receipt of chemotherapy.

Deficiency of MMR proteins (dMMR status) is common in Lynch syndrome and is present in about $15-20 \%$ of sporadic cancers (52). Functional impairment of the DNA MMR system results in the accumulation of insertion/deletion lesions at loci of DNA repeat sequences termed microsatellites, thereby producing a phenotype known as MSI. Some molecular markers such as MSI also have a side prevalence. Overall MSI-H status and BRAF mutation (more frequently detected in sporadic MSI $\mathrm{CRC}$ ) are more frequently diagnosed in proximal CRC (53). In these patients, better prognosis associated with MSI status is not attenuated by $B R A F$ mutations (54). $B R A F$ mutations were frequently seen also in sessile serrate adenoma pathway and in sporadic MSI-H CRC, both of which were associated with DNA methylation (55). Analyzing CRCs for MSI and dMMR status with IHC staining has become a useful strategy for identifying patients who should undergo genetic evaluation for Lynch syndrome and for deciding which patients could withhold adjuvant chemotherapy, because of a more favorable prognosis associated with the MSI status (56). Published systematic reviews and meta-analysis in all stages of disease showed that MSI CRCs are associated with better OS compared to MSS ones (35-40\% of reduced risk) (57). Also, in MSI CRCs, there is evidence for an inferior benefit associated with adjuvant chemotherapy compared to MSS tumors (58). The role of BRAF mutations was presented only in 8 studies of this metaanalysis (range $=7.9-56.7 \%$ ), but only in 2 studies MSI status was confirmed to be an independent positive predictor of OS 


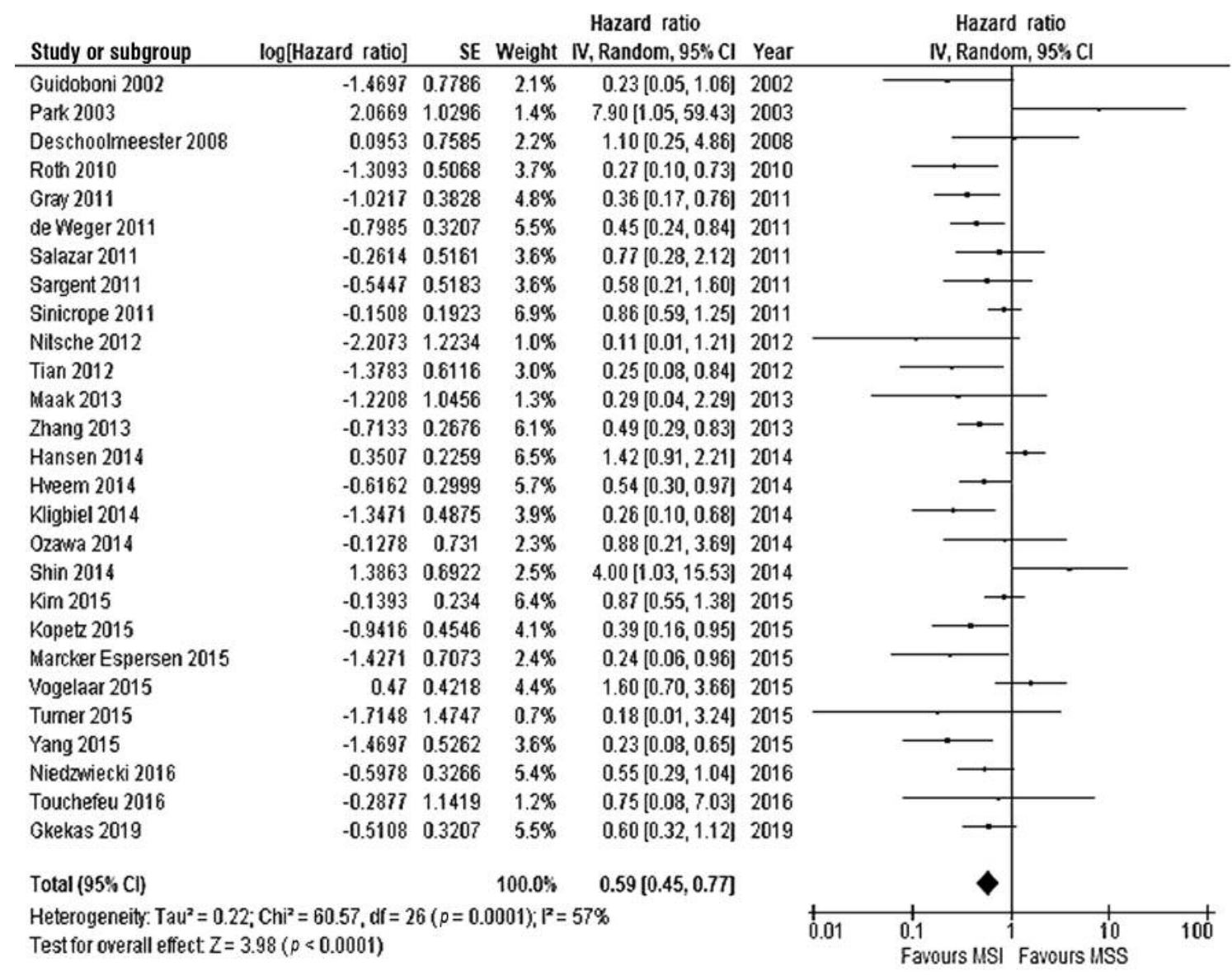

Figure 3. Meta-analysis of disease-free survival for MSI vs. MSS colorectal cancer.

with respect to $B R A F$ mutations in the multivariate analysis Overall, the role of $B R A F$ mutations in early CRC is, however, still debated in MSI stage II CRC (59-61). Recently, CRC subtypes have been proposed based on distinct global gene expression profiles. One proposed molecular classification system suggests the presence of four unique clinically relevant molecular subtypes with distinguishing features. The CMS1 (MSI-like) subgroup contains most MSI-H tumors. The MSIlike subtype is also enriched for tumors with a $\mathrm{CpG}$ island methylator phenotype (CIMP) and mutations in the BRAF oncogene. This subgroup is associated with a good prognosis but this classification is not yet ready for incorporation into prognostic stratification in clinical practice.

Recent publications have highlighted MSI testing as relatively underused in the early stages of disease. In an analysis of 152,993 adults including 17,218 younger adult patients with CRC, only $28.2 \%$ and $43.1 \%$ underwent MMR testing, respectively (62). Older age, uninsured, recto-sigmoid, and nonsurgical cases were those associated with no receipt of testing. Similar data have been reported by Thiebault et al. in 1,269 CRCs cases, where MSI status was evaluated only in $10.9 \%$ (63). Instead, MSI status has recently gained relevance for treatment strategies in an advanced setting, where immunotherapy has provided evidence of activity in pretreated MSI CRCs. In fact, in a phase 2 study, Overman et al. have observed an overall response rate of $31 \%$ in 74 MSI CRC patients, with eight cases having responses lasting 12 months or longer (64).

Standardization of MMR status testing and a general implementation in the current clinical practice are of noteworthy importance. Diagnosis of MSI is realized via PCR amplification of specific microsatellite repeats. The standard diagnostic method for MSI, advocated by the National Cancer Institute, involves PCR analyses of tumor and normal tissues using five microsatellite markers, two for mononucleotide repeats (BAT26 and BAT25) and three for dinucleotide repeats (D2S123, D5S346, and D17S250) $(65,66)$. There is, however, evidence that IHC analysis is a simple and more available method representing a good surrogate for MSI status. Recently, the American Society for Clinical Pathology (ASCP), College of 
Table II. MSI status and outcome data available in the included studies.

\begin{tabular}{|c|c|c|c|c|c|c|c|c|c|c|}
\hline \multirow[t]{2}{*}{ Author } & \multirow[t]{2}{*}{ Year } & \multirow[t]{2}{*}{$\begin{array}{c}\text { MSI-H } \\
(\%)\end{array}$} & \multirow[t]{2}{*}{$\begin{array}{c}\text { BRAF } \\
\text { mutation }(\%)\end{array}$} & \multirow[t]{2}{*}{$\begin{array}{l}\text { Adjuvant } \\
\text { ct }(\%)\end{array}$} & \multicolumn{2}{|c|}{$\begin{array}{c}\text { MSI-H } \\
\text { evaluation }\end{array}$} & \multirow[t]{2}{*}{$\begin{array}{l}\text { DFS or } \\
\text { RFS }\end{array}$} & \multirow[t]{2}{*}{ OS } & \multirow[t]{2}{*}{$\begin{array}{l}\text { Type of } \\
\text { analysis }\end{array}$} & \multirow[t]{2}{*}{$\begin{array}{c}\text { Quality of } \\
\text { paper }\end{array}$} \\
\hline & & & & & Biomarkers & $\mathrm{IHC}$ & & & & \\
\hline Aparicio & 2013 & 28.5 & NA & 7 & $\geq 3 / 5$ & & NA & $\sqrt{ }$ & UVA & 6 \\
\hline Curran & 1999 & 14 & NA & 0 & $\geq 2 / 4$ & & NA & $\sqrt{ }$ & UVA & 9 \\
\hline De Weger & 2011 & 17 & NA & $50^{\#}$ & $\geq 2 / 5$ & & $\sqrt{ }(\mathrm{RFI})$ & $\sqrt{ }$ & UVA & 8 \\
\hline Deschoolmeester & 2008 & 12.4 & NA & NA & & $\mathrm{x}$ & $\sqrt{ }$ & $\sqrt{ }$ & MVA & 5 \\
\hline Donada & 2010 & 9.6 & NA & 100 & $\geq 3 / 5$ & & NA & $\sqrt{ }$ & MVA & 7 \\
\hline Gray & 2011 & 14 & NA & 56 & & $\mathrm{x}$ & $\sqrt{ }$ & NA & MVA & 7 \\
\hline Gryfe & 2000 & 26.5 & NA & NA & $\geq 2 / 5$ & & NA & $\sqrt{ }$ & UVA & 7 \\
\hline Guidoboni & 2001 & 57.5 & NA & 12.7 & $\geq 2 / 5$ & & $\sqrt{ }$ & $\sqrt{ }$ & MVA & 7 \\
\hline Hansen & 2014 & 29 & NA & 0 & NA & & $\sqrt{ }$ & $\sqrt{ }$ & MVA & 6 \\
\hline Hveem & 2014 & 19 & NA & 0 & $\geq 2 / 5$ & & $\sqrt{ }$ & $\sqrt{ }$ & MVA & 9 \\
\hline Kevans & 2011 & 12 & NA & 0 & & $\mathrm{x}$ & NA & $\sqrt{ }$ & UVA & 5 \\
\hline Kim & 2015 & 14.7 & NA & 85.8 & & $\mathrm{x}$ & $\sqrt{ }$ & $\sqrt{ }$ & MVA & 8 \\
\hline Klingbiel & 2014 & 21.8 & 50 & 100 & $\geq 3 / 10$ & & $\sqrt{ }$ & $\sqrt{ }$ & UVA & 9 \\
\hline Kopetz & 2015 & 19.2 & NA & 29.8 & $\geq 2 / 5$ & $\mathrm{x}$ & $\sqrt{ }(\mathrm{ROR})$ & NA & UVA & 9 \\
\hline Krajewska & 2015 & 21 & NA & 0 & $\geq 2 / 6$ & & NA & $\sqrt{ }$ & UVA & 9 \\
\hline Lanza & 2006 & 18.5 & NA & 18.1 & $\geq 30 \%$ & & NA $\sqrt{ }$ & $\sqrt{ }(\mathrm{CSS})$ & MVA & 9 \\
\hline Maak & 2013 & 23.5 & NA & 2.2 & $\geq 2 / 5$ & & $\sqrt{ }(\mathrm{DMFS})$ & $\mathrm{NA}$ & UVA & 9 \\
\hline Malesci & 2007 & 17 & $56.7 * *$ & 46 & & $\mathrm{x}$ & NA & $\sqrt{ }$ & UVA & 7 \\
\hline Marcker Espersen & 2016 & 22.9 & NA & 0 & & $\mathrm{x}$ & $\sqrt{ }$ & NA & MVA & 8 \\
\hline Nazemalhosseini Mojarad & 2016 & 31.4 & NA & NA & $\geq 2 / 5$ & & NA & $\sqrt{ }$ & UVA & 6 \\
\hline Niedzwiecki & 2016 & 26 & NA & 49 & & $\mathrm{x}$ & $\sqrt{ }(\mathrm{RFI})$ & NA & MVA & 9 \\
\hline Nitsche & 2012 & 26 & 15 & NA & $\geq 2 / 5$ & & $\sqrt{ }(\mathrm{DMFS})$ & NA & MVA & 8 \\
\hline Ozawa & 2014 & NA & NA & NA & & $\mathrm{x}$ & $\sqrt{ }$ & NA & UVA & 8 \\
\hline Park & 2003 & 17 & NA & 0 & & $\mathrm{x}$ & $\sqrt{ }$ & $\sqrt{ }$ & UVA & 7 \\
\hline Roth & 2010 & 21 & $7.9^{\wedge}$ & 100 & $\geq 3 / 10$ & & $\sqrt{ }$ & $\sqrt{ }$ & MVA & 9 \\
\hline Salazar & 2011 & 18 & 11 & NA & & $\mathrm{x}$ & $\sqrt{ }$ & NA & UVA & 9 \\
\hline Samowitz & 2001 & 15 & NA & NA & $\geq 2 / 5$ & & NA & $\sqrt{ }$ & MVA & 8 \\
\hline Sargent & 2011 & 31.5 & NA & 0 & & $\mathrm{x}$ & $\sqrt{ }(\mathrm{TTR})$ & $\sqrt{ }$ & MVA & 9 \\
\hline Shin & 2014 & 13 & NA & 87.5 & $\geq 2 / 5$ & & $\sqrt{ }$ & NA & MVA & 6 \\
\hline Sinicrope & 2011 & 21.1 & NA & 50 & & $\mathrm{x}$ & $\sqrt{ }$ & $\sqrt{ }$ & MVA & 9 \\
\hline Slik & 2017 & 21 & $15^{\wedge}$ & 30 & & $\mathrm{x}$ & $\sqrt{ }$ & $\sqrt{ }$ & MVA & 7 \\
\hline Tian & 2012 & 30 & 11.7 & 20 & $\geq 2 / 5^{*}$ & $\mathrm{x}$ & $\sqrt{ }(\mathrm{DMFS})$ & NA & UVA & 5 \\
\hline Touchefeu & 2016 & 27 & NA & 19 & $\geq 2 / 5$ & & $\sqrt{ }$ & $\sqrt{ }$ & MVA & 6 \\
\hline Turner & 2015 & 6 & NA & 22 & & $\mathrm{x}$ & $\sqrt{ }(\mathrm{RFS})$ & $\sqrt{ }$ & UVA & 8 \\
\hline Vogelaar & 2015 & 23 & 19 & 0 & $1 / 1$ & & $\sqrt{ }$ & $\sqrt{ }$ & UVA & 5 \\
\hline Wang & 2003 & 21 & NA & $<5 \%$ & $1 / 1$ & & NA & $\sqrt{ }$ & UVA & 7 \\
\hline Yang & 2015 & 21 & NA & 56 & $\geq 2 / 5$ & & $\sqrt{ }$ & NA & MVA & 6 \\
\hline Zhang & 2013 & 14.6 & NA & 33 & & $\mathrm{x}$ & $\sqrt{ }$ & NA & MVA & 9 \\
\hline
\end{tabular}

*Analysis was performed with IHC and biomarker analysis in the 2 cohorts analysed; RFS: relapse-free survival; RFI: relapse-free interval; UVA: univariate analysis; MVA: multivariate analysis; ROR: risk of relapse; \#adjuvant immunotherapy; NA: not available; ^ ${ }^{\circ}$ outcome according to MSI status analysed independent of BRAF status; **in sporadic MSI colorectal cancer.

American Pathologists (CAP), Association for Molecular Pathology (AMP), and the American Society of Clinical Oncology (ASCO) implemented evidence-based guidelines for biomarker testing in CRC (67). They stated that clinicians should order MMR status testing in patients with CRC for the identification of patients at high risk for Lynch syndrome and/or prognostic stratification. In our meta-analysis, the OS advantage of MSI status was larger in studies where molecular analysis was performed by using established microsatellite markers, even if the panel of biomarkers was slightly different in various studies.

Our analysis has some intrinsic limitations. Firstly, we observed notable heterogeneity due to retrospective nature of the study, and the inclusion of relatively different populations. We took this into account with a random effect model analysis and with subgroup analysis and meta-regression. A significant difference was observed for the type of MMR evaluation (biomarker vs. IHC analysis) and quality/size of publications. Secondly, this meta-analysis was based on published data 


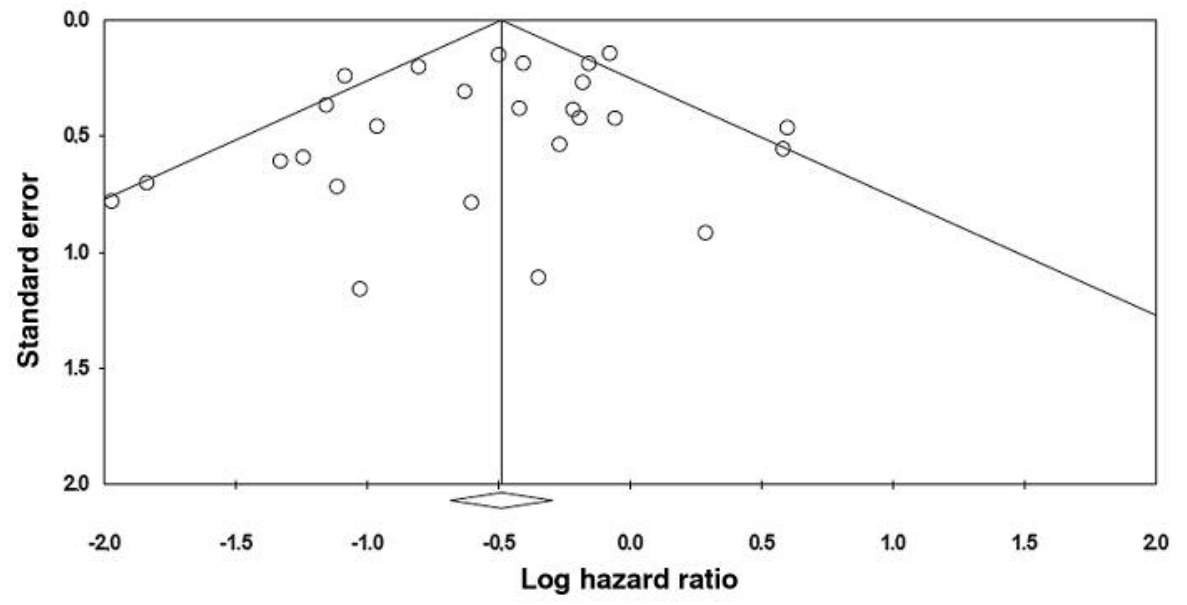

Figure 4. Funnel plot for publication bias in overall survival analysis.

instead of individual patient data. Thirdly, analysis was not performed according to different side (right $v s$. left CRC), pT stage (pT4 vs. pT3), and for colon vs. rectal cancers, even if the latter was the minority. Finally, our results address the prognostic and not the predictive role of MSI status in stage II CRC. The strength of our analysis is represented by the overall number of patients included (more than 12,000 of CRC subjects from 39 studies), the independent prognostic significance of MSI status according to multivariate analysis, and the lack of significant and obvious biases with funnel plot and Egger's test. So, this is the first and largest meta-analysis of published studies that establishes the prognostic significance of MSI status in stage II CRC and indicates the need for implementing it in current practice for all resected patients. The current 2017 National Comprehensive Cancer Network practice guidelines suggest detection of MSI status for all patients with stage II disease and patients with no other high-risk features or pT4 stage, which indicates no adjuvant treatment (68). Similar suggestions are offered by the 2013 European Society of Medical Oncology guidelines for early CRC where it is stated that MSI/MMR may be useful for identifying a small subset of stage II patients who are at a very low risk of recurrence and in whom the benefits of chemotherapy are very unlikely (69). While other prognostic factors such as gene signatures and CDX2 are developing, but are still not entirely implemented in clinical practice, we can affirm that in stage II CRC patients that are MSI/dMMR, there is $40 \%$ less risk of death and relapse. In these cases, if other adverse prognostic factors are excluded, adjuvant chemotherapy could be discussed and may be avoided by MSI stage II CRC patients.

\section{Conflicts of Interest}

The Authors have no conflicts of interest to declare regarding this study.

\section{Authors' Contributions}

FP, MG, GT: Concept, design, statistical analysis and final review; MC, AC, AV, AG: Data collection; EP, DC, LT, SB: Final review and approval.

\section{References}

1 Siegel RL, Miller KD and Jemal A: Cancer statistics, 2018. CA Cancer J Clin 68(1): 7-30, 2018. PMID: 29313949. DOI: 10.3322/caac. 21442

2 QUASAR Collaborative Group: Adjuvant chemotherapy versus observation in patients with colorectal cancer: a randomised study. Lancet 370(9604): 2020-2029, 2007. PMID: 18083404. DOI: 10.1016/S0140-6736(07)61866-2

3 Kannarkatt J, Joseph J, Kurniali PC, Al-Janadi A and Hrinczenko B: Adjuvant chemotherapy for stage II colon cancer: A clinical dilemma. J Oncol Pract 13(4): 233-241, 2017. PMID: 28399381. DOI: $10.1200 / J O P .2016 .017210$

4 Romiti A, Rulli E, Pilozzi E, Gerardi C, Roberto M, Legramandi L, Falcone R,Pacchetti I, Marchetti P and Floriani I: Exploring the prognostic role of microsatellite instability in patients with stage II colorectal cancer: A systematic review and metaanalysis. Clin Colorectal Cancer 16(2): e55-e59, 2016. PMID: 27670891. DOI: 10.1016/j.clcc.2016.08.007

5 Thibodeau SN, Labianca R, Hamilton SR, French AJ, Kabat B, Foster NR, Torri V, Ribic C, Grothey A, Moore M, Zaniboni A, Seitz JF, Sinicrope F and Gallinger S: Defective mismatch repair as a predictive marker for lack of efficacy of fluorouracil-based adjuvant therapy in colon cancer. J Clin Oncol 28(20): 32193226, 2010. PMID: 20498393. DOI: 10.1200/JCO.2009.27.1825

6 Hutchins G, Southward K, Handley K, Magill L, Beaumont C, Stahlschmidt J, Richman S, Chambers P, Seymour M, Kerr D, Gray R and Quirke P: Value of mismatch repair, KRAS, and BRAF mutations in predicting recurrence and benefits from chemotherapy in colorectal cancer. J Clin Oncol 29(10): 12611270, 2011. PMID: 21383284. DOI: 10.1200/JCO.2010.30.1366

7 Thibodeau SN, Bren G and Schaid D: Microsatellite instability in cancer of the proximal colon. Science 260(5109): 816-819, 1993. PMID: 8484122. DOI: $10.1126 /$ science. 8484122 
8 Parmar MKB, Torri $\mathrm{V}$ and Stewart L: Extracting summary statistics to perform meta-analyses of the published literature for survival endpoints. Stat Med 17(24): 2815-2834, 1998. PMID: 9921604. DOI: 10.1002/(SICI)1097-0258(19981230)17:24< 2815::AID-SIM110>3.0.CO;2-8

9 Higgins JPT and Thompson SG: Quantifying heterogeneity in a meta-analysis. Stat Med 21(11): 1539-1558, 2002. PMID: 12111919. DOI: $10.1002 / \mathrm{sim} .1186$

10 Egger M, Smith GD, Schneider M and Minder C: Bias in meta analysis detected by a simple, graphical test. BMJ 14: 1-16, 2005. PMID: 9310563. DOI: 10.1136/bmj.315.7109.629

11 Wells GA, Shea B, O'Connell D, Peterson J, Welch V, Losos M and Tugwell P: The Newcastle-Ottawa Scale (NOS) for assessing the quality of nonrandomized studies in meta-analyses. Ottawa Hosp Res Inst (3): 1-4, 2013. DOI: 10.2307/632432

12 Aparicio T, Schischmanoff O, Poupardin C, Soufir N, Angelakov C, Barrat C, Levy V, Choudat L, Cucherousset J, Boubaya M, Lagorce C, Guetz GD, Wind P and Benamouzig R: Deficient mismatch repair phenotype is a prognostic factor for colorectal cancer in elderly patients. Dig Liver Dis 45(3): 245-250, 2013. PMID: 23102497. DOI: 10.1016/j.dld.2012.09.013

13 Curran B, Lenehan K, Mulcahy H, Tighe O, Bennett MA, Kay EW, O'Donoghue DP, Leader M and Croke DT: Replication error phenotype, clinicopathological variables, and patient outcome in Dukes' B stage II (T3,N0,M0) colorectal cancer. Gut 46(2): 200204, 2000. PMID: 10644313. DOI: 10.1136/gut.46.2.200

14 De Weger VA, Turksma AW, Voorham QJM, Euler Z, Bril H, van den Eertwegh AJ, Bloemena E, Pinedo HM, Vermorken JB, van Tinteren H, Meijer GA and Hooijberg E: Clinical effects of adjuvant active specific immunotherapy differ between patients with microsatellite-stable and microsatellite-instable colon cancer. Clin Cancer Res 18(3): 882-889, 2012. PMID: 22156611. DOI: $10.1158 / 1078-0432 . C C R-11-1716$

15 Deschoolmeester V, Van Damme N, Baay M, Claes K, Van Marck E, Baert FJ, Wuyts W, Cabooter M, Weyler J, Vermeulen P, Lardon F, Vermorken JB and Peeters M: Microsatellite instability in sporadic colon carcinomas has no independent prognostic value in a Belgian study population. Eur J Cancer 44(15): 2288-2295, 2008. PMID: 18707864. DOI: 10.1016/ j.ejca.2008.06.043

16 Donada M, Bonin S, Nardon E, De Pellegrin A, Decorti G and Stanta G: Thymidilate synthase expression predicts longer survival in patients with stage II colon cancer treated with 5flurouracil independently of microsatellite instability. J Cancer Res Clin Oncol 137(2): 201-210, 2011. PMID: 20387074. DOI: 10.1007/s00432-010-0872-1

17 Gryfe R, Kim H, Hsieh ET, Aronson MD, Holowaty EJ, Bull $\mathrm{SB}$, Redston $\mathrm{M}$ and Gallinger S: Tumor microsatellite instability and clinical outcome in young patients with colorectal cancer. $\mathrm{N}$ Engl J Med 342(2): 69-77, 2000. PMID: 10631274.

18 Gray RG, Quirke P, Handley K, Lopatin M, Magill L, Baehner FL, Beaumont C, Clark-Langone KM, Yoshizawa CN, Lee M, Watson D, Shak S and Kerr DJ: Validation study of a quantitative multigene reverse transcriptase-polymerase chain reaction assay for assessment of recurrence risk in patients with stage II colon cancer. J Clin Oncol 29(35): 4611-4619, 2011. PMID: 22067390. DOI: 10.1200/JCO.2010.32.8732

19 Guidoboni M, Gafà R, Viel A, Doglioni C, Russo A, Santini A, Del Tin L, Macrì E, Lanza G, Boiocchi M and Dolcetti R: Microsatellite instability and high content of activated cytotoxic lymphocytes identify colon cancer patients with a favorable prognosis. Am J Pathol 159(1): 297-304, 2001. PMID: 11438476. DOI: 10.1016/S0002-9440(10)61695-1

20 Halling KC, French AJ, McDonnell SK, Burgart LJ, Schaid DJ, Peterson BJ, Moon-Tasson L, Mahoney MR, Sargent DJ, O'Connell MJ, Witzig TE, Farr GH Jr., Goldberg RM and Thibodeau SN: Microsatellite instability and 8p allelic imbalance in stage B2 and C colorectal cancers. JNCI Cancer Spectr 91(0027-8874): 1295-1303, 1999. PMID: 10433618. DOI: $10.1093 /$ jnci/91.15.1295

21 Hansen TF, Kjær-Frifeldt S, Christensen RD, Morgenthaler S, Blondal T, Lindebjerg J, Sørensen FB and Jakobsen A: Redefining high-risk patients with stage II colon cancer by risk index and microRNA-21: results from a population-based cohort. Br J Cancer 111(7): 1285-1292, 2014. PMID: 25051407. DOI: $10.1038 /$ bjc .2014 .409

22 Hveem TS, Merok MA, Pretorius ME, Novelli M, Bævre MS, Sjo OH, Clinch N, Liestøl K, Svindland A, Lothe RA, Nesbakken A and Danielsen HE: Prognostic impact of genomic instability in colorectal cancer. Br J Cancer 110(8): 2159-2164, 2014. PMID: 24642618. DOI: 10.1038/bjc.2014.133

23 Kim JE, Hong YS, Kim HJ, Kim KP, Lee JL, Park SJ, Lim SB, Park IJ, Kim CW, Yoon YS, Yu CS, Kim JC, Hoon KJ and Kim TW: Defective mismatch repair status was not associated with DFS and OS in stage II colon cancer treated with adjuvant chemotherapy. Ann Surg Oncol 22(S3): 630-637, 2015. PMID: 26271397. DOI: 10.1245/s10434-015-4807-6

24 Kevans D, Wang LM, Sheahan K, Hyland J, O'Donoghue D, Mulcahy H and O'Sullivan J: Epithelial-mesenchymal transition (EMT) protein expression in a cohort of stage II colorectal cancer patients with characterized tumor budding and mismatch repair protein status. Int J Surg Pathol 19(6): 751-760, 2011. PMID: 21791486. DOI: 10.1177/1066896911414566

25 Klingbiel D, Saridaki Z, Roth AD, Bosman FT, Delorenzi M and Tejpar S: Prognosis of stage II and III colon cancer treated with adjuvant 5-fluorouracil or FOLFIRI in relation to microsatellite status: Results of the PETACC-3 trial. Ann Oncol 26(1): 126132, 2015. PMID: 25361982. DOI: 10.1093/annonc/mdu499

26 Kopetz S, Tabernero J, Rosenberg R, Jiang ZQ, Moreno V, Bachleitner-Hofmann T, Lanza G, Stork-Sloots L, Maru D, Simon I, Capellà G and Salazar R: Genomic classifier ColoPrint predicts recurrence in stage II colorectal cancer patients more accurately than clinical factors. Oncologist 20(2): 127-133, 2015. PMID: 25561511. DOI: 10.1634/theoncologist.2014-0325

27 Lanza G, Gafà R, Santini A, Maestri I, Guerzoni L and Cavazzini L: Immunohistochemical test for MLH1 and MSH2 expression predicts clinical outcome in stage II and III colorectal cancer patients. J Clin Oncol 24(15): 2359-2367, 2006. PMID: 16710035. DOI: $10.1200 / J C O .2005 .03 .2433$

28 Krajewska M, Kim H, Kim C, Kang H, Welsh K, Matsuzawa S, Tsukamoto M, Thomas RG, Assa-Munt N, Piao Z, Suzuki K, Perucho M, Krajewski S and Reed JC: Analysis of apoptosis protein expression in early-stage colorectal cancer suggests opportunities for new prognostic biomarkers. Clin Cancer Res 11(15): 5451-5461, 2005. PMID: 16061861. DOI: 10.1158/10780432.CCR-05-0094

29 Maak M, Simon I, Nitsche U, Roepman P, Snel M, Glas AM, Schuster T, Keller G, Zeestraten E, Goossens I, Janssen KP, Friess $\mathrm{H}$ and Rosenberg $\mathrm{R}$ : Independent validation of a prognostic genomic signature (ColoPrint) for patients with stage II colon cancer. Ann Surg 257(6): 1053-1058, 2013. PMID: 23295318. DOI: 10.1097/SLA.0b013e31827c1180 
30 Malesci A, Laghi L, Bianchi P, Delconte G, Randolph A, Torri V, Carnaghi C, Doci R, Rosati R, Montorsi M, Roncalli M, Gennari L and Santoro A: Reduced likelihood of metastases in patients with microsatellite-unstable colorectal cancer. Clin Cancer Res 13(13): 3831-3839, 2007. PMID: 17606714. DOI: 10.1158/1078-0432.CCR-07-0366

31 Marcker Espersen ML, Linnemann D, Christensen IJ, Alamili M, Troelsen JT and Høgdall E: SOX9 expression predicts relapse of stage II colon cancer patients. Hum Pathol 52: 38-46, 2016. PMID: 26980019. DOI: 10.1016/j.humpath.2015.12.026

32 Mojarad EN, Kashfi SMH, Mirtalebi H, Taleghani MY, Azimzadeh P, Savabkar S, Pourhoseingholi MA, Jalaeikhoo H, Asadzadeh Aghdaei H, Kuppen PJ and Zali MR: Low level of microsatellite instability correlates with poor clinical prognosis in stage II colorectal cancer patients. J Oncol 2016: 2196703 , 2016. PMID: 27429617. DOI: $10.1155 / 2016 / 2196703$

33 Niedzwiecki D, Frankel WL, Venook AP, Ye X, Friedman PN, Goldberg RM, Mayer RJ, Colacchio TA, Mulligan JM, Davison TS, O'Brien E, Kerr P, Johnston PG, Kennedy RD, Harkin DP, Schilsky RL, Bertagnolli MM, Warren RS and Innocenti F: Association between results of a gene expression signature assay and recurrence-free interval in patients with stage II colon cancer in cancer and leukemia group B 9581 (Alliance). J Clin Oncol 34(25): 3047-3053, 2016. PMID: 27432924. DOI: 10.1200/ JCO.2015.65.4699

34 Nitsche U, Rosenberg R, Balmert A, Schuster T, Slotta-Huspenina J, Herrmann P, Bader FG, Friess H, Schlag PM, Stein U and Janssen KP: Integrative marker analysis allows risk assessment for metastasis in stage II colon cancer. Ann Surg 256(5): 763-771, 2012. PMID: 23095620. DOI: 10.1097/SLA.0b013e318272de87

35 Ozawa T, Kazama S, Akiyoshi T, Murono K, Yoneyama S, Tanaka T, Tanaka J, Kiyomatsu T, Kawai K, Nozawa H, Kanazawa T, Yamaguchi H, Ishihara S, Sunami E, Kitayama J, Morikawa T, Fukayama $\mathrm{M}$ and Watanabe T: Nuclear notch3 expression is associated with tumor recurrence in patients with stage II and III colorectal cancer. Ann Surg Oncol 21(8): 2650-2658, 2014. PMID: 24728738. DOI: 10.1245/s10434-014-3659-9

36 Parc Y, Gueroult S, Mourra N, Serfaty L, Fléjou JF, Tiret E and Parc R: Prognostic significance of microsatellite instability determined by immunohistochemical staining of MSH2 and MLH1 in sporadic T3N0M0 colon cancer. Gut 53(3): 371-375, 2004. PMID: 14960518. DOI: 10.1136/gut.2003.019190

37 Roth AD, Tejpar S, Delorenzi M, Yan P, Klingbiel D, Fiocca R, d'Ario G, Cisar L, Labianca R, Cunningham D, Nordlinger B, Bosman F and Van Cutsem E: Prognostic role of KRAS and BRAF in stage II and III resected colon cancer: Results of the translational study on the PETACC-3, EORTC 40993, SAKK 60-00 trial. J Clin Oncol 28(3): 466-474, 2010. PMID: 14960518. DOI: 10.1200/JCO.2009.23.3452

38 Salazar R, Roepman P, Capella G, Moreno V, Simon I, Dreezen C, Lopez-Doriga A, Santos C, Marijnen C, Westerga J, Bruin S, Kerr D, Kuppen P, van de Velde C, Morreau H, Van Velthuysen L, Glas AM, Van't Veer LJ and Tollenaar R: Gene expression signature to improve prognosis prediction of stage II and III colorectal cancer. J Clin Oncol 29(1): 17-24, 2011. PMID: 21098318. DOI:10.1200/JCO.2010.30.1077

39 Samowitz WS, Curtin K, Ma KN, Schaffer D, Coleman LW, Leppert M and Slattery ML: Microsatellite instability in sporadic colon cancer is associated with an improved prognosis at the population level. Cancer Epidemiol Biomarkers Prev 10(9): 917923, 2001. PMID: 11535541.
40 Sargent DJ, Resnick MB, Meyers MO, Goldar-Najafi A, Clancy T, Gill S, Siemons GO, Shi Q, Bot BM, Wu TT, Beaudry G, Haince JF and Fradet Y: Evaluation of guanylyl cyclase C lymph node status for colon cancer staging and prognosis. Ann Surg Oncol 18(12): 3261-3270, 2011. PMID: 21533822. DOI: 10.1245/s10434-011-1731-2

41 Shin US, Cho SS, Moon SM, Park SH, Jee SH and Jung E: Coloproctology is microsatellite instability really a good prognostic factor of colorectal cancer? Coloproctology 30(1): 28-34, 2014.

42 Sinicrope FA, Foster NR, Thibodeau SN, Marsoni S, Monges G, Labianca R, Kim GP, Yothers G, Allegra C, Moore MJ, Gallinger S and Sargent DJ: DNA mismatch repair status and colon cancer recurrence and survival in clinical trials of 5fluorouracil-based adjuvant therapy. J Natl Cancer Inst 103(11): 863-875, 2011. PMID: 21597022. DOI: 10.1093/jnci/djr 153

43 Slik K, Kurki S, Korpela T, Carpén O, Korkeila E and Sundström J: Ezrin expression combined with MSI status in prognostication of stage II colorectal cancer. PLoS One 12(9): 1-15, 2017. DOI: 10.1371/journal.pone.0185436

44 Tian S, Roepman P, Popovici V, Michaut M, Majewski I, Salazar R, Santos C, Rosenberg R, Nitsche U, Mesker WE, Bruin S, Tejpar S, Delorenzi M, Bernards R and Simon I: A robust genomic signature for the detection of colorectal cancer patient. A robust genomic signature for the detection of colorectal cancer patients with microsatellite instability phenotype and high mutation frequency. J Pathol 228(4): 586-595, 2012. PMID: 22926706. DOI: $10.1002 /$ path.4092

45 Touchefeu Y, Provost-Dewitte M, Lecomte T, Morel A, Valo I, Mosnier JF, Bossard C, Eugène J, Duchalais E, Chetritt J, Guyetant S, Bézieau S, Senellart H, Caulet M, Cauchin E and Matysiak-Budnik T: Clinical, histological, and molecular risk factors for cancer recurrence in patients with stage II colon cancer. Eur J Gastroenterol Hepatol 28(12): 1394-1399, 2016. PMID: 27606947. DOI: 10.1097/MEG.0000000000000725

46 Turner N, Wong HL, Templeton A, Tripathy S, Whiti Rogers T, Croxford M, Jones I, Sinnathamby M, Desai J, Tie J, Bae S, Christie M, Gibbs P and Tran B: Analysis of local chronic inflammatory cell infiltrate combined with systemic inflammation improves prognostication in stage II colon cancer independent of standard clinicopathologic criteria. Int J Cancer 138(3): 671-678, 2016. PMID: 26270488. DOI: 10.1002/ijc.29805

47 Vogelaar FJ and van Erning FN: The prognostic value of microsatellite instability, KRAS, BRAF and PIK3CA mutations in stage II colon cancer patients. Mol Med 21(1): 1, 2015. DOI: 10.2119/molmed.2015.00220

48 Yang L, Sun Y, Huang XE, Yu DS, Zhou JN, Zhou X, Li DZ and Guan X: Carcinoma microsatellite instability status as a predictor of benefit from fluorouracil-based adjuvant chemotherapy for stage II rectal cancer. Asian Pacific J Cancer Prev 16(4): 1545-1551, 2015. PMID: 25743829. DOI: 10.7314/APJCP.2015.16.4.1545

49 Zhang J-X, Song W, Chen Z-H, Wei JH, Liao YJ, Lei J, Hu M, Chen GZ, Liao B, Lu J, Zhao HW, Chen W, He YL, Wang HY, Xie D and Luo JH: Prognostic and predictive value of a microRNA signature in stage II colon cancer: a microRNA expression analysis. Lancet Oncol 14(13): 1295-1306, 2013. PMID: 24239208. DOI: 10.1016/S1470-2045(13)70491-1

50 Gkekas I, Novotny J, Fabian P, Nemecek R, Palmqvist R, Strigård K, Pecen L, Svoboda T, Gurlich R and Gunnarsson U: Deficient mismatch repair as a prognostic marker in stage II colon cancer patients. Eur J Surg Oncol 45(10): 1854-1861, 2019. DOI: $10.1016 /$ j.ejso.2019.05.023 
51 Böckelman C, Engelmann BE, Kaprio T, Hansen TF and Glimelius B: Risk of recurrence in patients with colon cancer stage II and III: A systematic review and meta-analysis of recent literature. Acta Oncol (Madr) 54(1): 5-16, 2015. PMID: 25430983 DOI: 10.3109/0284186X.2014.975839

52 de la Chapelle A and Hampel H: Clinical relevance of microsatellite instability in colorectal cancer. J Clin Oncol 28(20): 3380-3387, 2010. PMID: 20516444 DOI: 10.1200/JCO.2009.27.0652

53 Lin L, Chen G, Xu C, Wang H, Wu Y and Fang M: Evaluation and identification of factors related to KRAS and BRAF gene mutations in colorectal cancer: A meta-analysis. J Cancer Res Ther 12(7): 191, 2016. PMID: 28230016. DOI:10.4103/09731482.200601

54 Seppälä TT, Böhm JP, Friman M, Lahtinen L, Väyrynen VM, Liipo TK, Ristimäki AP, Kairaluoma MV, Kellokumpu IH, Kuopio TH and Mecklin JP: Combination of microsatellite instability and BRAF mutation status for subtyping colorectal cancer. Br J Cancer 112(12): 1966-1975, 2015. PMID: 25973534. DOI: 10.1038/bjc.2015.160

55 Kambara T, Simms LA, Whitehall VL, Spring KJ, Wynter CV, Walsh MD, Barker MA, Arnold S, McGivern A, Matsubara N, Tanaka N, Higuchi T, Young J, Jass JR and Leggett BA: BRAF mutation is associated with DNA methylation in serrated polyps and cancers of the colorectum. Gut 53(8): 1137-1144, 2004. PMID: 15247181

56 Popat S, Hubner R and Houlston RS: Systematic review of microsatellite instability and colorectal cancer prognosis. J Clin Oncol 23(3): 609-618, 2005. PMID: 15659508. DOI: 10.1200/ JCO.2005.01.086

57 Guastadisegni C, Colafranceschi M, Ottini L and Dogliotti E: Microsatellite instability as a marker of prognosis and response to therapy: A meta-analysis of colorectal cancer survival data. Eur J Cancer 46(15): 2788-2798, 2010. PMID: 20627535. DOI: 10.1016/j.ejca.2010.05.009

58 Des Guetz G, Schischmanoff O, Nicolas P, Perret GY, Morere JF and Uzzan B: Does microsatellite instability predict the efficacy of adjuvant chemotherapy in colorectal cancer? A systematic review with meta-analysis. Eur J Cancer 45(10): 1890-1896, 2009. PMID: 19427194. DOI: 10.1016/j.ejca.2009.04.018

59 Bläker H, Alwers E, Arnold A, Herpel E, Tagscherer KE, Roth W, Jansen L, Walter V, Kloor M, Chang-Claude J, Brenner H and Hoffmeister M: The association between mutations in BRAF and colorectal cancer-specific survival depends on microsatellite status and tumor stage. Clin Gastroenterol Hepatol 17(3): 455-462.e6, 2018. PMID: 29660527. DOI: 10.1016/j.cgh.2018.04.015

60 Domingo E, Camps C, Kaisaki PJ, Parsons MJ, Mouradov D, Pentony MM, Makino S, Palmieri M, Ward RL, Hawkins NJ, Gibbs P, Askautrud H, Oukrif D, Wang H, Wood J, Tomlinson E, Bark Y, Kaur K, Johnstone EC, Palles C, Church DN, Novelli M, Danielsen HE, Sherlock J, Kerr D, Kerr R, Sieber O, Taylor JC and Tomlinson I: Mutation burden and other molecular markers of prognosis in colorectal cancer treated with curative intent: results from the QUASAR 2 clinical trial and an Australian community-based series. Lancet Gastroenterol Hepatol 1253(18): 1-9, 2018. DOI: 10.1016/S2468-1253(18)30117-1

61 de Cuba EM, Snaebjornsson P, Heideman DA, van Grieken NC, Bosch LJ, Fijneman RJ, Belt E, Bril H, Stockmann HB, Hooijberg E, Punt CJ, Koopman M, Nagtegaal ID, Coupé VH, Carvalho B and Meijer GA: Prognostic value of BRAF and KRAS mutation status in stage II and III microsatellite instable colon cancers. Int J Cancer 138(5): 1139-1145, 2016. PMID: 26376292. DOI: $10.1002 / \mathrm{ijc} .29855$
62 Shaikh T, Handorf EA, Meyer JE, Hall MJ and Esnaola NF: Mismatch repair deficiency testing in patients with colorectal cancer and nonadherence to testing guidelines in young adults. JAMA Oncol e173580, 2017. PMID: 29121143. DOI: 10.1001/jamaoncol.2017.3580

63 Thiebault Q, Defossez G, Karayan-Tapon L, Ingrand P, Silvain $\mathrm{C}$ and Tougeron D: Analysis of factors influencing molecular testing at diagnostic of colorectal cancer. BMC Cancer 17(1): 765, 2017. DOI: 10.1186/s12885-017-3759-6

64 Overman MJ, McDermott R, Leach JL, Lonardi S, Lenz HJ, Morse MA, Desai J, Hill A, Axelson M, Moss RA, Goldberg MV, Cao ZA, Ledeine JM, Maglinte GA, Kopetz S and André $\mathrm{T}$ : Nivolumab in patients with metastatic DNA mismatch repairdeficient or microsatellite instability-high colorectal cancer (CheckMate 142): An open-label, multicentre, phase 2 study. Lancet Oncol 18(9): 1182-1191, 2017. PMID: 28734759. DOI: 10.1016/S1470-2045(17)30422-9

65 Boland CR, Thibodeau SN, Hamilton SR, Sidransky D, Eshleman JR, Burt RW, Meltzer SJ, Rodriguez-Bigas MA, Fodde R, Ranzani GN and Srivastava S: A National Cancer Institute workshop on microsatellite instability for cancer detection and familial predisposition: Development of international criteria for the determination of microsatellite instability in colorectal cancer. Cancer Res 58: 5248-5257, 1998. PMID: 9823339. DOI: 10.1158/0008-5472.can-06-1114

66 Rigau V, Sebbagh N, Olschwang S, Paraf F, Mourra N, Parc Y and Flejou JF: Microsatellite instability in colorectal carcinoma. The comparison of immunohistochemistry and molecular biology suggests a role for hMSH6 [correction of hMLH6] immunostaining. Arch Pathol Lab Med 127(6): 694-700, 2003. PMID: 12741892. DOI: 10.1043/1543-2165(2003)127<694:MIICC>2.0.CO;2

67 Sepulveda AR, Hamilton SR, Allegra CJ, Grody W, CushmanVokoun AM, Funkhouser WK, Kopetz SE, Lieu C, Lindor NM, Minsky BD, Monzon FA, Sargent DJ, Singh VM, Willis J, Clark J, Colasacco C, Rumble RB, Temple-Smolkin R, Ventura CB and Nowak JA: Molecular biomarkers for the evaluation of colorectal cancer: Guideline from The American Society for Clinical Pathology, College of American Pathologists, Association for Molecular Pathology, and the American Society of Clinical Oncology. J Clin Oncol 35(13): 1453-1496, 2017. PMID: 28165299. DOI: 10.1200/JCO.2016.71.9807

68 Benson AB, Venook AP, Cederquist L, Chan E, Chen YJ, Cooper HS, Deming D, Engstrom PF, Enzinger PC, Fichera A, Grem JL, Grothey A, Hochster HS, Hoffe S, Hunt S, Kamel A, Kirilcuk N, Krishnamurthi S, Messersmith WA, Mulcahy MF, Murphy JD, Nurkin S, Saltz L, Sharma S, Shibata D, Skibber JM, Sofocleous CT, Stoffel EM, Stotsky-Himelfarb E, Willett CG, Wu CS, Gregory KM and Freedman-Cass D: Colon Cancer, Version 1.2017, NCCN Clinical Practice Guidelines in Oncology. J Natl Compr Canc Netw 15(3): 370-398, 2017. PMID: 28275037. DOI: 10.1093/med/9780199664535.003.0012

69 Labianca R, Nordlinger B, Beretta GD, Mosconi S, Mandalà M, Cervantes A and Arnold D; ESMO Guidelines Working Group: Early colon cancer: ESMO clinical practice guidelines for diagnosis, treatment and follow-up. Ann Oncol 24: vi64-72, 2013. PMID: 24078664. DOI: 10.1093/annonc/mdt354

Received October 28, 2019

Revised November 5, 2019

Accepted November 8, 2019 